\title{
Illegal Migration - A Threat To India
}

\author{
Smt. Saheli Naik \\ Assistant Professor of political scienceKabi Sukanta Mahavidyalaya, BhadreswarHooghly, \\ West Bengal, India.
}

\section{INTRODUCTION}

The end of Cold War, rising tide of globalization, environmental degradation, international terrorism have opened up a new vista of state security. We are well aware of the fact that the military security is a traditional one. But with the advent of Globalization, the global strategic environment is in a state of constant flux. This change of world politics and the core determinant of international order and security adhere to several non-traditional sectors with a much enhanced role of economic, political and social forces. Thus we can say that the cold war has therefore marked a shift in the study and analysis of security and world order from a traditional framework to a non-traditional approach. However according to Mely Caballero-Anthony, non-traditional security threats may be defined as "[1] "challenges to the survival and well-being of people and states that arise primarily out of non-military sources such as climate change, cross-border environmental degradation and resource depletion, infection diseases, natural disasters, irregular migration, food shortages, people smuggling, drug trafficking and other forms of transnational crime".

The above definition seems to highlight some specific characteristics of non-traditional security, viz; non-military nature, transnational scopes i.e, neither domestic nor purely state related but people related matters which affect both governmental and civilian population. For the purpose of comprehensive analysis, one can identify six broad branches of the non-traditional security- (I) international terrorism, (ii) trans-national organized crime, (iii) environmental security, (iv) illegal migration, (v) energy security, and (vi) human security.

\section{MIGRATION A PROBLEM TO US}

Illegal migration comprises of people across national borders in a way that violates the immigration laws of the destination country. Some countries have millions of illegal immigrations . ${ }^{[2]}$ Immigration as well as illegal migration is overwhelmingly upward from a poorer to a richer country. ${ }^{[3]}$ The thinkers of the west tells us that the reason of immigration from one country to the other are - poverty, overpopulation, family reunification, wars and war problems, unemployment etc. thus the immigration takes place by border crossing in the most time, overstaying a visa, same marriages etc.

\section{TERMINOLOGY OF ILLEGAL MIGRATION}

There have been campaigns to discourage the use of the term 'illegal immigrants' in many countries since 2007, generally based on the argument that the act of immigration may be illegal in some cases, but the people themselves are not illegal. In the United States a 'Drop the I-word' campaign was launched in 2010 to advocate the use of terms such as "undocumented immigrants" or "unauthorized immigrants" to refer to the foreign nationals who reside in a country illegally. ${ }^{[4]}$ News associations that have discontinued or discouraged the use of the adjective "illegal" to describe people include the US Associated Press, ${ }^{[5]}$ UK Press Associations, European Journalism observatory, ${ }^{[6]}$ European Journalism centre, Association of European Journalists and Australian Media and Australian Press Council. ${ }^{[7]}$

\section{ILLEGAL MIGRATION A PROBLEM TO INDIA BANGLADESH}

Millions of illegal immigrants live in India. They are from the neighboring countries. Most of them come by crossing border. After independence and before independence they came due to communal riots and divide and rule process. Precise figures are not available, but the numbers run in tens of millions at 10 million from Bangladesh, others from Pakistan, Afghanistan and others. During the Bangladesh Liberation War at least 10 million Bangladesh -citizens came to India illegally to seek refuge from widespread rape and genocide. ${ }^{[8]}$ According to home ministry at least 1.4 million Bangladeshi crossed the border in that time. ${ }^{[9]}$ In an analysis number says that near about 91000 Bangladeshi nationals might have crossed over to India every year during 1981-1991. [10] According to pro-Indian scholar, the trip to India from Bangladesh is one of the cheapest in the world, with a trip costing around Rs. 2000. Most of the Bengali speaking people deported from Maharashtra as 
illegal immigrants are originally Indian citizens from West Bengal. Police would demand Rs. 2000-2500 from each of the detained Bengali speaking people for their release.2001 census report gives information about migrants but not exclusively illegal immigrants. As per the report, Bangladesh -citizens were the largest group of migrants in India followed by Pakistan. ${ }^{[11]}$ It also says that there are 3,084,826 people are crossed the border without passport and came to India from Bangladesh., Assam alone gives a figure of 2 millions people crossing the border without permission. ${ }^{[12]}$ Report states that Bangladeshi are cultural similar to Bengali people in India, hence can establish a far better future in India than they could in Bangladesh ${ }^{[13]}$ for a very small price . This false identity can be bolstered with false documentation available for as little as Rs: 200 and essentially can even make them part of 'VoteBank'. This migration also makes population expansion of the country mostly Muslims in the Assam and border area. According to 1991 census report, Muslim population growth rate in border state/s sometime gets higher than Muslim growth rate in India, as an example during 1981-1991, Muslim growth rate in India was $52.8 \%$ whereas Muslim growth rate in WestBenagal was $61.05 \%$.

It is also reported that Muslim growth rate was higher compare with Hindu growth rate ${ }^{[14]}$, as an example, Muslim growth rates were $41.89 \%$ and $61.05 \%$ in Assam(during 1971-1991) and West Bengal(during 19811991) respectively which are higher than Hindu growth rates $35.42 \%$ and $13.67 \%$. More details are depicted in the table below:

\begin{tabular}{|c|c|c|c|c|c|c|}
\hline \multirow{2}{*}{$\begin{array}{l}\text { Period } \\
\text { Groups }\end{array}$} & \multicolumn{3}{|c|}{ Growth rate $(\%)$ during 1971-1991 } & \multicolumn{3}{|c|}{ Growth rate $(\%)$ during 1991-2001 } \\
\hline & Muslims & Hindus & Difference & Muslims & Hindus & Difference \\
\hline Assam & 41.89 & 35.42 & 5.53 & 14.95 & 9.3 & 4.35 \\
\hline All India & 93.25 & 23.04 & 60.79 & 70 & 19.3 & 5.3 \\
\hline Period & \multicolumn{3}{|c|}{ Growth rate (\%) during 1981-1991 } & \multicolumn{3}{|c|}{ Growth rate (\%) during 1991-2001 } \\
\hline Groups & Muslims & Hindus & Difference & Muslims & Hindus & Difference \\
\hline $\begin{array}{l}\text { West } \\
\text { Bengal }\end{array}$ & 61.05 & 13.67 & 45.62 & 64.26 & 16.1 & 51.84 \\
\hline All India & 52.8 & 22.9 & 30.1 & 50 & 20.3 & 29.3 \\
\hline
\end{tabular}

\section{PAKISTAN AND BURMA}

India has thousands of people from Pakistan living illegally according to one figure from 2009, it was above $7,700^{[16]}$. The Burmese immigrants are mostly found in the Indian state of Mizoram and small number is found in Delhi. They are estimated $50000-100,000$ residing in India. ${ }^{[17]}$.

\section{AGITATION}

In Assam, agitation against immigration of Bangladesh started from early 1979 led by All Assam Students Union. Their demand was to put a stop on the influx of immigrants. It gradually turns into violent form between Assamese and Bengalis, mostly in Muslim. In 1985, Indian Government signed Assam Accord with the leaders of the agitation. ${ }^{[18]}$ But it becomes difficult to distinguish illegal immigrants and the local Bengali people. BJP and Congress have discriminated the local population from illigal immigrants. After 1991 census, the changing demographic patterns in the border districts became more visible. It created anxiety in India the most of the time. BJP formed the Government in 1998 and started building Indo - Bangladesh border [19] in WB, Tripura and Mizoram. West Bengal too is affected by this problem. However some Indian Newspaper reported that the State Govt. has reports that illegal Bangladesh -citizens or migrants have trickled into parts of rural Bengal over the years and settled down as Sharecroppers with the help of Left leaders. Though the Bangladeshi Govt. denied it totally.

\section{WHAT SUPREME COURT SAYS}

In the year 2005, the Supreme court ruled "Illegal Migrants Act "as unconstitutional ${ }^{[20]}$ with reference to the Sinha report ${ }^{[21]}$. In August 2008, the Delhi high court dismissed a petition by a Bangladeshi national against her deportation. The High court ruled that the illegal Bangladeshi immigrants pose a danger to India's internal security.

\section{OUR CONCERN}

Apart from immigrants, a large numbers of smugglers cross the border along WB into India. They are being engaged in smuggling goods from India into Bangladesh to avoid high tariff imposed on some Indian goods by Bangladesh Govt.. Bangladeshi women are trafficked to India, Middle East for labor and sexual goods. 
According to CEDAW report $1 \%$ of foreign prostitutes in India and $2.7 \%$ of prostitutes in Kolkata are from Bangladesh. ${ }^{[22]}$

So illegal immigrants are threats to India in terms of increasing population, unemployment and crime.

\section{INTRACTABLE ILLEGAL IMMIGRATION}

The presence of a large number of Bangladeshis mainly muslims, has reportedly changed the demographic landscape in some border districts of Assam, Tripura and West Bengal during 90's. Samir GuhaRoy Of Indian Statistical Institute called the Govt. estimates of illegal Bangladeshis "motivated exaggerated". After examining the population growth and demographic statistic 'Roy' instead states that a significant numbers of internal migration is sometimes thought to be illegal immigrants. An analysis of the numbers by Roy revealed that on average around 91,000 Bangladeshi nationals might have crossed over to India every year during the years from 1981 to 1991 but how many of them were identified or pushed back is not known. Though steps have been taken in the form of updating National Register Of Citizens(NRC) by the Assam Govt. under the supervision of the Supreme Court, doubts have been raised that the NRC update process is marred by maximum chances of large number of Bangladeshis migrants living illegally in the state to have their names enrolled as Indian Citizen.

\section{INDIAN GOVERNMENT STEPS}

After NDA had formed Govt. on 2014 , PM Modi took several steps to check illegal migration into Assam from Bangladesh. On April 2015 at a rally in Guwahati, BJP national President Amit Shah said that BJP Govt. will give citizenship to all Hindu immigrants who has to flee from Bangladesh due to religious persecution. ${ }^{[23]}$ After formation of Govt. in Rajya Sabha Union minister of state Kiren Rijiju said, "there are reports that some Bangladeshi nationals are able to manage to enter Assam and other parts of the country illegally despite several checks and control measures taken along the international border". He said, to maintain national security, the Govt. had already taken a number of steps, including strengthening of BSF and equipping it with modern and sophisticated equipment. According to the minister, gaps between the border outposts have been reduced \& patrolling along international boundary intensified. He also said that construction of border roads and fencing has been accelerated and surveillance equipment provided. Rijiju also said that the Govt. also urged Bangladesh to take effective steps to check the illegal movement of its nationals into India.

In the time of campaigning (2014), PM Modi (then he was Gujrat CM) in Assam widely told that after forming of government his ministry would take steps against the "illegal immigrants".In June, 2015 Modi visited Bangladesh and he did a bilateral treaty with Sheikh Hasina (Bangladesh Prime minister). At that time the two Nations faced an atmosphere of greater bilateral trust and warmth than we have seen since the assassination of Sheikh Mujibur Rahman in 1975. From her part, Hasina has dealt firmly with anti-India terrorism and has sent many of the worst war criminals of the 1971 freedom struggle those who murdered and raped in the name of keeping Pakistan Islamic to jail or the gallons. She also told that it is a good time that Bangladesh will become a proper secular state, despite its constitution formally retaining Islam as state religion.

\section{XI.}

Indo-Bangladesh Border agreement says that ${ }^{[24]}$ -

\section{THE AGREEMENT}

First: India will change its immigration policy to have two classes of immigrants one is free entry for those who are seeking asylum against Islamist violence and intimidation. This will mean mostly Hindus and chakmas who inhabit some border areas \& will cater even to the Sangh policy of India offering a home to all Hindus anywhere in the world.

Second: India should offer specific immigration quotas for future immigrants provided the Bangaldesh Govt. agrees to provide information on where the immigrants are from \& where they may go back when the work permits expires. India can also guarantee that they will not be deported against their will \& will be given residency and work permits.

Third:_In return, Bangladesh must sign a free tread \& investment treaty whereby Indian businesses can invest in that country without being subjected to discrimination. Investing in Bangladesh will create jobs there and make our own companies more competitive. India should sign a 'Nafta' like treaty with Bangladesh. If it happens, South Asia will have the makings of European Union(EU) and avoid Pakistan.

\section{OUR EXPECTATION}

This agreement will create the illegal immigrants an entity of a State. We can say that those people will be considered as a citizen. The investment \& trade will make the relationship of the two countries more hard. If the free trading will start many force of the Pakistani army and deep state to end its own unremitting hostility to India. But right now, we can't count on any such thing and a free trading SAARC minus Pakistan is a good enough option for enhancing regional prosperity. 
On the other hand it won't be easy for Modi to make this shift instance, but if he manages it, he will have arrived as a true statesman who has a vision for the future. He could also consider a political benefit, a potential shift in Muslim opinion about the BJP. It may be well worth the risk.

\section{REFERENCES}

[1] Caballero - Anthony, 'An Introduction' Understanding Non-traditional security Pp 1-4

[2] NBC News3 ${ }^{\text {rd }}$ Sept,2013- http://nbcpolitics.nbcnews.com/_news/2013/04/11/17691515bythe-numbershow-america-tallies-its-111-million-undocumented-immigrants - accessed on February 28, 2016

[3] Taylor, Mark, December 2007 - The Drivers of immigration in contemporary society: Unequal Distribution of Resources and opportunities Human Ecology P.35(6):775-776 do :: 10.1007/s 10745007 $-9111-\mathrm{Z}$

[4] "Drop the I word campaign" A campaign against undocumented immigrants in America https://en.wikipedia.org/wiki/Illegal_immigration - accessed on February 27, 2016

[5] "Illegal Immigrants no more" - Associated Press Blog, 2013 April 2 https://en.wikipedia.org/wiki/Illegal_immigration - accessed on February 27, 2016

[6] Nazhmidinova, Rukshona - $5^{\text {th }}$ May, 2014 - "User Generated Racism: Russia's media and migrants" The European Journalism observatory

[7] 'Asylumseekers', illega immigrants and entry without a visa - Australian Press Council, 5 May, 2014 https://en.wikipedia.org/wiki/Illegal_immigration - accessed on February 27, 2016

[8] “India's 'Mexican' Problem: Illegal immigration from Bangladesh" - IBMTimes 6Feb, 2012 http://www.ibtimes.com/indias-mexican-problem-illegal-immigration-bangladesh-213993 - accessed on February 26, 2016

[9] Hans Gunter Branch, John Grin, Ursula Oswald(2009). Facing Global Environment Change: Environmental, Human, Energy, Food, Health and Water Security. Springer .p.304 - ISBN 3540684883

[10] Villagers left in limbo by border fence

[11] http://news.bbc.co.uk/2/hi/programmes/from_our_own_correspondent/4653810.stm - accessed on February 27, 2016

[12] “CensusofIndia2001.DataHighlights:Migrationtable”P-19 - Accessed on February 27, 2016 "Census of India, 2001, Data Highlights: Migration Table” P-33

[13] India's Mexican Problem: Illegal Immigration from Bangladesh - IBM Times - 2012-02-06 http://www.ibtimes.com/indias-mexican-problem-illegal-immigration-bangladesh-213993- accessed on February 25, 2016

[14] Report by Sachar Committee - Appendix tabled 3.1-3.5 Page - 271 to 278

[15] Report by Sacher Committee, census Reference Tables - Population by religious communities

[16] More illegal immigrants from Afghanistan than Pakistan - Hindustan Times 2011-11-14 https://en.wikipedia.org/wiki/Illegal_immigration_to_India accessed on February 27, 2016

[17] India Ignores illegal Migration - GCIM.org - https://en.wikipedia.org/wiki/Illegal_immigration_to_India accessed on February 27, 2016

[18] Illegal Migration into Assam Satp.org- - https://en.wikipedia.org/wiki/Illegal_immigration_to_India accessed on February 27, 201

[19] AnandabazarPatrika,Bengalidaily,Kolkata. $8^{\text {Th }}$ March,1995https://en.wikipedia.org/wiki/Illegal_immigrati on_to_India - accessed on February 27, 2016

[20] IMDT Act is the biggest barrier to deportation says Supreme Court - The Hindu https://en.wikipedia.org/wiki/Illegal_immigration_to_India - accessed on February 27, 2016

[21] Act arouses aggression: SC - Time Of India - https://en.wikipedia.org/wiki/Illegal_immigration_to_India - accessed on February 27, 2016

[22] Committee on the Elimination of Discrimination Against women, United Nations. http://www.un.org/esa/gopher-data/ga/cedaw/17/country/Bangladesh/C-BGD3-4.EN - accessed on February 26, 2016

[23] BJP:Indiancitizenship for Bangladesh Hindu refuge http://timesofindia.indiatimes.com/india/BJPIndiancitizenship-for-Bangladesh-Hindu-refugees/articleshow/47069473.cms - accessed on May 19, 2016

[24] Why PM Modi should offer Sheikh Hasina a win-win deal on illegal immigrants http://m.firstpost.com/india/why-pm-modi-should-offer-sheikh-hasina-a-win-win-deal-on-illegalimmigrants-2281332.html - accessed on May 18, 2016 